\title{
韵 \\ SUBYEKTIVITAS DAN OBYEKTIVITAS DALAM STUDI AL-QUR'AN (Menimbang Pemikiran Paul Ricoeur dan Muhammad Syahrur)
}

\author{
Anwar Mujahidin \\ Sekolah Tinggi Agama Islam Negeri Ponorogo \\ pranotogomo@yahoo.com
}

\begin{abstract}
Abstrak
Perdebatan antara penggunaan akal (bi ar-ra 'yi) dan penggunaan riwayat (bi al-ma` r) dalam studi al-Qur an ternyata tidak mampu mengarahkan pemikir Islam kontemporer untuk menemukan metodologi tafsir yang bisa dipertanggungjawabkan. Perdebatan keduanya justru membawa pemikiran Islam jumud dan berkutat pada pertarungan idiologi antar kelompok yang semakin menjauhkan umat dari petunjuk al-Qur`an. Artikel ini membahas tentang pemikiran Paul Recoeur dan Muhammad Syahrur dalam studi al-Qur`an, khususnya tentang isu subyektifitas dan obyektifitas. Paul Ricoeur berpendapat bahwa penafsir tidak perlu terjebak dalam subyektifitas, karena teks memiliki makna obyektif dalam struktur internalnya. Dengan cara itu penafsiran selain akan menemukan makna obyektif teks, juga akan menemukan cakrawala dunia yang di arah oleh teks. Sehingga penafsir meleburkan diri dalam dunia teks dan tidak terjebak dalam kejumudan dan kungkungan masa lalu. Hal itu dipertegas oleh Syahrur bahwa kembali kepada al-Qur' an tidak berarti kembali ke masa lalu. Menafsirkan al-Qur' an adalah menggali pandangan hidup alQur' an atau makna dari totalitas struktur al-Qur' an. Makna al-Qur' an juga memberikan acuan kepada dunia kontemporer.
\end{abstract}

Abstract

SUBJECTIVITYANDOBJECTIVITYINTHE STUDYOFAL-QUR'AN(Considering the Thoughts of Paul Ricoeur and of Muhammad Shahrur). The debates between the use of reason (bi ar -ra 'yi) and the use of history (bi al-ma' $r$ ) in the study of the Koran prove unable to direct the contemporary Islamic thinkers to find a methodology of interpretations that can be accounted for. The debates both would bring Islamic thought to be old-fashioned and dwell on the ideological battles between the groups which increasingly 
draw people away from the instructions of the Koran. This article discusses the thoughts of Paul Recoeur and Muhammad Shahrur in the study of the Koran, particularly on the issue of subjectivity and objectivity. Paul Ricoeur argues that the interpreter does not need to be stuck in subjectivity, because the text has an objective meaning in its internal structure. In that way, the interpretation will not only find the meaning of the text objectively, but it also will find a world horizon in the direction of the text. So the interpreters must immerse themselves in the world of text and do not get stuck in stagnation and confines of the past. This was reinforced by Shahrur that back to the Koran does not mean a return to the past. Interpret the Koran is digging the way of life of the Koran or the meaning of the totality of its structure. The meaning of the Koran also gives reference to the contemporary world.

Kata Kunci: Tafsir; Hermeneutika; Teks, al-Qur’an; Subyektif; Obyektif.

\section{A. Pendahuluan}

Al-Qur'an adalah teks inti dalam sejarah peradaban Arab Islam. Demikianlah pernyataan Nașr Hamid Abu Zaid. Lebih lanjut ia menyatakan bahwa bukan suatu simplikasi jika dikatakan bahwa peradaban Arab Islam adalah "Peradaban Teks". Hal tersebut tidak berarti bahwa teks itu sendiri yang membangun peradaban, sebab teks apapun tidak dapat membangun peradaban dan menegakkan ilmu pengetahuan serta kebudayaan. Yang dapat membangun peradaban dan menegakkan kebudayaan adalah dialektika manusia dengan realitas di satu pihak dan dialektika dengan teks di pihak lain. ${ }^{1}$

Kebutuhan pengkajian al-Qur`an sudah mulai terasa sejak masa awal sejarah penyebaran Islam dan mencapai respon keilmuan yang cukup penting pada masa Abbasiyah dimana Islam telah menjadi agama bagi orang-orang non Arab, di luar bangsa di mana al-Qur`an pertama kali diturunkan dan sekaligus pemilik bahasa yang digunakan oleh Tuhan mengartikulasikan firman-firman-Nya. Manna’ al-Qațtān menyatakan bahwa sampai masa tadwin (masa kodifikasi keilmuan Islam) telah tumbuh karya-karya tafsir yang

${ }^{1}$ Nașr Hamid Abu Zaid, Mahfūm al-Naș, Dirāsah fì 'Ulūm al-Qur'ān, (Kairo: alHai'ah al-Mișriyyah al-Ammah li al-Kitāb), h. 11, Terjemah lihat Nașr Hamid Abu Zaid, Tekstualitas al-Qur'an, Kritik terhadap Ulumul Qur'an, Penerjemah: Khoiron Nahdliyyin, (Yogykarta: LkiS, 2001), h. 1. 
berdiri sendiri terlepas dari bidang hadis dengan menafsirkan alQur'an sesuai dengan urutan ayat dan surat sebagaimana yang telah tersusun dalam mushaf. Mereka menafsirkan al-Qur'an dengan assunnah, pendapat sahabat, tabi'in dan tabi' at-tabi'in yang kadangkadang disertai penjelasan (tarjih) kandungan hukumnya. Di antara karya tafsir dengan metode dan pendekatan tersebut adalah: ${ }^{2}$ karya Ibn Majah (w 273 H), karya ibn Jarir at-Tabarỉ (w 310 H), karya Abu Bakr bin al-Munzìr an-Naisābūri (w. 318 H).

Kemudian setelah ilmu keIslaman dan lainnya berkembang pesat, saat para ulama telah menguasai berbagai disiplin ilmu, karya-karya ilmiah dari berbagai bidang bermunculan, maka karya tafsir juga ikut bermunculan dengan pesat dengan diwarnai oleh latar belakang pendidikan masing-masing pengarangnya. Masingmasing penafsir mempunyai kecenderungan dan arah pembahasan tersendiri yang berbeda dengan yang lain. Di antara mereka ada yang cenderung kepada pembahasan aspek balaghah seperti imam az-Zamakhsyari, ${ }^{3}$ kepada pembahasan aspek hukum syariat seperti imam Abu al-Su'ūd.

Sayangnya, interaksi keilmuan yang mengagumkan pada masa tadwin tersebut bercampur aduk atau dibayang-bayangi dengan perdebatan-perdebatan teologis, sehingga mimbar petualangan akademik untuk menemukan metode ilmiah dalam studi ilmuilmu keislaman khususnya ilmu al-Qur`an dan tafsir al-Qur`an dihantui oleh para mutakallimin yang khawatir akan terjadinya pendangkalan akidah dan kesesatan.

Para ilmuan harus menerima kenyataan pahit karena menguatnya nalar kalam dalam masyarakat Islam. Tanpa menyederhanakan dialektika keilmuan yang terjadi, kemenangan mutakallimin tersebut dapat dirasakan dengan jelas pada masa pertengahan dari sejarah Islam. As-Suyuți sebagaimana dikutip oleh Nașr Hamid Abu Zaid menyatakan bahwa ilmu-ilmu keIslaman khususnya al-Qur'an dan hadis adalah ilmu yang sudah matang dan final (nadijah wa ihtarakat). Untuk itu Abu Zaid dalam penelitiannya

${ }^{2}$ Manna al- Qațțān, Mabāhis fì 'Ulūm al-Qur'ān, (Riyāḍ: Mansyurāt al-'Aṣr alHadis, 1973), h. 341-342.

3‘Abd Al-Hayy al-Farmawi, Metode Tafsir Mawadhu'iy Suatu Pengantar, Penerj mah: Suryan A. Jamrah, (Jakarta: Rajawali Pers, 1996), h. 14-15. 
terhadap kitab al-Itqān karya as-Suyuți menyimpulkan bahwa karya tersebut hanya sebagai karya pengulangan, apa yang ditulisnya hanyalah kumpulan dari ilmu-ilmu yang sudah dirumuskan ulama terdahulu. ${ }^{4}$

Ibn Taimiyyah, salah seorang ulama abad ke-8 Hijriyah menegaskan bahwa apabila telah diketahui pengertian atau tafsir alQur'an dengan as-sunnah maka tidak diperlukan lagi pendapat ahli bahasa dan yang lainnya. Bagi setiap mukmin tidak diperkenankan berbicara mengenai agama kecuali mengikuti apa yang datang dari Rasulullah saw, para sahabat dan orang-orang yang mengikuti jejak mereka dari para tabi'in, yang tak seorangpun diantara mereka terbukti melakukan pertentangan dengan al-Qur'an dengan rasionalitasnya. ${ }^{5}$

Az-Zarkasi seorang ulama yang wafat pada tahun $794 \mathrm{H}$, penulis kitab al-Burhān fi 'Ulūm al-Qur'ān, salah satu kitab rujukan utama dalam bidang ilmu-ilmu al-Qur'an juga menyimpulkan bahwa yang benar menurut ilmu tafsir adalah apa yang berasal dari jalur naql (periwayatan) seperti asbāb al-nuzūl (sebab turunnya ayat), an-naskh (diberlakukan atau dihapuskannya ketetapan hukum yang dikandung oleh suatu ayat yang belum jelas) ta'yin al-mubham (penjelasan terhadap ayat yang belum jelas), tabyin almujmal (penjelasan terhadap ayat yang masih umum). Apabila tidak didapatkan penafsiran yang cukup dari jalan naql, maka untuk mengetahui makna dan maksud dari ayat-ayat al-Qur'an adalah dengan jalan pemahaman pada penjelasan yang mu'tabar (terkenal dan diakui oleh kebanyakan ulama). ${ }^{6}$

Tafsir dengan pendekatan seperti itu, yang disebut tafsir bi al-ma'șūr menurut al-Qațțān wajib diikuti dan dipedomani karena ia adalah jalan pengetahuan yang benar dan merupakan jalan paling aman untuk menjaga diri dari ketergelinciran dan kesesatan dalam memahami kitabullah.?

Sebaliknya, tafsir yang mencoba merespon perkembangan

${ }^{4}$ Nașr Abu Zaid, Mahfūm an-Nas..., h. 13, lihat Abu Zaid, Tekstualitas..., h. 4

5'Abd al-Rahmān bin Muhammad bin Qāsim al-'Așim an-Najdi, Majmū' Fatāwā Syaikh al-Islām Ahmad bin Taimiyah, juz ke-13, (ttp : tpn, 1398 H).

${ }^{6}$ Badr ad-Dīn Muhammad bin 'Abd Allāh az-Zarkasi, al-Burhān fī 'Ulūm alQur'ān, juz ke-2, (Beirut: Dār al-Fikr, 1998), h. 188-189.

${ }^{7}$ Manna al- Qațțān, mabāhis fì ‘Ulūm..., h. 350. 
zaman dengan menghadirkan ilmu-ilmu seperti bahasa, sastra, dan filsafat sebagai ilmu bantu dalam menyingkap makna alQur'an adalah karya yang dilarang (haram) yang berarti juga haram megikutinya. Hal tersbut dikarenakan ketepatan dan kebenaran suatu pendapat tidak meyakinkan dan hanya bersifat dugaan dan perkiraan semata. Orang yang mengatakan sesuatu tentang agama Allah menurut dugaan semata berarti ia telah mengatakan terhadap Allah sesuatu yang tidak ia ketahui. ${ }^{8}$ Ibn Taymiyyah juga secara tegas mengklaim bawha sebab-sebab kesesatan dalam penafsiran alQur'an adalah adanya interaksi dengan para filosof. ${ }^{9}$

\section{B. Masalah Akademik}

Berbeda dengan Barat, dimana kegelapan zaman pertengahan melahirkan kebangkitan intelektual atau masa pencerahan dan mendorong modernisasi. Di dunia Islam seolah masa kegelapan sudah diubah dengan penerimaan dan ketabahan. Kemiskinan dan kemuduran kebudayaan dianggap sebagai ujian dari Tuhan. Memasuki abad ke-19 pemikiran Islam mendapat kesempatan kedua untuk bangkit. Bila zaman pertengahan kesempatan itu dikarenakan hadirnya karya-karya dari filsafat Yunani, pada masa modern ini momentum kebangkitkan datang dari pengaruh modernisasi di Barat, terutama diserukan oleh sarjana-sarjana Islam yang mendapat kesempatan sekolah di Barat. Salah satu contoh di Mesir adalah Rafah at-Tahtawi (1803-1873). Beliau adalah alumni al-Azhar yang dikirim untuk belajar di Paris. Sepulang dari Paris ia menyerukan kepada rakyat Mesir bahwa mereka harus belajar dari Barat. "Gerbang Ijtihad" (pemikiran bebas) harus di buka. Kaum ulama harus bergerak mengikuti zaman dan syariah harus beradaptasi dengan dunia modern. Namun seolah takdir menyatakan lain, dunia pemikiran Islam tak bisa lepas dari bayangbayang kelompok-kelompok yang menjaga kemurnian dan keaslian ajaran Islam.

Seruan Tahtawi di atas berbarengan dengan datangnya barat ke Negara-negara Islam dengan misi penjajahan. Masa studi Tahtawi di Perancis bersamaan dengan pendudukan al-Jazair oleh Perancis

\footnotetext{
${ }^{8}$ Ibid., h. 352.

9 'Abd al-Rahman, Majmū’ Fatāwā..., h. 206.
} 
dengan brutal. Fenomena ini jelas menimbulkan resistensi umat Islam terhadap Barat. Setidaknya hal ini dapat dilihat dari seruan Jamal al-Din al-Afgani (1839-1897). Setelah ia berkeliling ke Arab, Turki, Rusia dan Eropa, ia menjadi sangat cemas terhadap kekuatan dan kekuasaan Barat yang ada di mana-mana yang dia percaya hendak menghancurkan dunia Islam. Menurut al-Afghani hanya dengan mereformasi Islam dan tetap bertahan pada peradaban dan tradisi agama sendirilah, negara-negara Islam akan menjadi kuat kembali dan dapat menciptakan modernitas ilmiah versi mereka sendiri. ${ }^{10}$

Demikianlah sejarah kelam perkembangan studi ilmiah di dunia Islam, dua kali momentum kebangkitan itu hadir, namun hanya menyisakan ketakutan akan ancaman dunia luar, kekhawatiran pemikiran yang kebablasan, rasionalisme yang berpotensi meninggalkan agama dan lain setrusnya. Sekarang ini di era post kolonial, di saat negara-negara Islam sudah menjadi negara yang merdeka, maka saat yang tepat untuk segera menghapus segala penyakit mental, trauma masa lalu dan perasaan terancam oleh dunia luar, dan menyongsong masa depan dengan mental dan jiwa yang sehat. Bila hal ini tidak dilakukan maka ketakutan dan jiwa yang terancam akan terus menemukan pembenarnya, pertempuran Amerika dan Irak, Israel dan Palestina akan menjadi alasan selanjutnya di era kontemporer untuk memelihara kecurigaan kepada dunia di luar Islam dan berarti pula memelihara suasana permusuhan.

Problem riil dimasyarakat Islam seperti kebodohan, kemiskinan, kondisi ekonomi negara-negara Islam yang lemah harus dianggap cukup untuk menyadarkan alam pikiran akademisi muslim yang terus menerus memelihara mental paranoid. Dimana Islam yang dibela kemurniannya, namun khasiatnya tidak bisa dirasakan secara nyata oleh pemeluknya. Tentu menjadi ironis.

Kesadaran seperti itulah nampaknya yang membangkitkan Syahrur. Dalam pengantar bukunya al-Kitāb wa al-Qur'ān, Qirā’ah Mu'așirah, ia menyatakan bahwa telah berlalu paruh kedua dari abad ke-15 $\mathrm{H}$, atau bertepatan dengan paruh terakhir abad $20 \mathrm{M}$,

${ }^{10}$ Keren Amstrong, Berperang Demi Tuhan, Fundamentalisme dalam Islam,Kristen dan Yahudi, (Bandung: Mizan dan Serambi, 2000), h. 243-244. 
tetapi peradaban Islam sejak permulaan abad ke-20 masih saja menyuguhkan Islam sebagai aqidah dan etika tanpa menyentuh dimensi filosofis dari aqidah Islam. Peradaban Islam mengalami stagnasi dan tidak mampu memecahkan problem fundamental pemikiran ke-Islaman, karena masih dipenuhi berbagai taqlid tentang konsep qaḍ` dan qadar, faham jabariah, problematika pengetahuan, konsep negara, problem sosial ekonomi, demokrasi dan penafsiran atas sejarah. Syahrur merumuskan bahwa masalah utama dari semuanya adalah ${ }^{11}$ :

1. Tidak adanya pegangan berupa metode ilmiah objektif. Syarat utama penelitian ilmiah yang obyektif adalah melakukan studi teks tanpa mengikut sertakan sentimen apapun.

2. Adanya prakonsepsi terhadap semua masalah sebelum kajian dilakukan. Contohnya penelitian mengenai "Posisi Perempuan dalam Islam". Para peneliti muslim berkesimpulan terlebih dahulu sebelum mengadakan penelitian. Mereka berasumsi bahwa posisi perempuan dalam Islam sudah proporsional dan Islam adalah agama yang bersikap paling adil terhadap perempuan. Kemudian peneliti tersebut mengarang buku mengenai perempuan.

3. Pemikiran Islam belum memanfaatkan konsep-konsep dalam filsafat humaniora dan tidak berinteraksi dengan dasar-dasar teorinya. Tidak mungkin seluruh hasil pemikiran manusia sejak zaman Yunani hingga saat ini adalah salah semua. Pasti di antaranya ada yang sempit ada dan ada yang luas, ada yang relevan dan ada yang tidak relevan. Meskipun demikian sebelum berinteraksi dengan hasil pemikiran tersebut, setiap muslim harus memiliki standar fleksibel yang memungkinkan kita berinteraksi dengan orang lain tanpa ada rasa takut.

4. Tidakadanya teori Islam kontemporer dalamilmu humaniora yang disimpulkan secara langsung dari al-Qur`an. Sebuah teori yang memberi metode tentang cara berpikir ilmiah pada diri setiap muslim, memberikan rasa percaya diri, dan

${ }^{11}$ Muhammad Syahrur, al-Kitāb wa al-Qur `ān, Qirā’ ah Mu'așirah, (Damaskus: al-Ahali, 1990), h. 29-32. 
berani berinteraksi dengan nilai apapun yang dihasilkan manusia tanpa melihat aqidahnya.

5. Saat ini kaum muslimin sedang mengalami krisis ilmu fiqih.

Niat yang kuat untuk keluar dari krisis pemikiran dan sakit mental yang traumatik terhadap dunia luar dengan mengarahkan dunia akademik di era kontemporer lebih berorientasi kepada usaha menemukan metode-metode ilmiah yang dapat dipertanggung jawabkan secara ilmiah dalam menafsirkan al-Qur`an juga dirasakan di Indonesia. Tanda-tanda ke arah pengkajian yang ilmiah ini setidaknya terlihat dari apa yang ditulis oleh Quraish Syihab, beliau menyimpulkan bahwa di antara faktor-faktor yang mengakibatkan kekeliruan dalam penafsiran antara lain: Subyektifitas mufasir, Kekeliruan dalam menerapkan metode dan kaidah, Kedangkalan dalam ilmu-ilmu alat, Kedangkalan pengetahuan tentang materi uraian (pembicaraan) ayat, Tidak memperhatikan konteks, baik asbab an-nuzul, hubungan antar ayat, maupun kondisi sosial masyarakat, dan tidak memperhatikan siapa pembicara dan terhadap siapa pembicaraan ditujukan. ${ }^{12}$

Mengklaim adanya pandangan subyektif penafsir yang mempengaruhi hasil penafsirannya sebagai akibat tidak mengikuti metode yang diwajibkan oleh kelompok tertentu dan kemudian menuduhnya sebagai tafsir yang menyesatkan adalah sikap idiologis yang menjerumuskan studi al-Qur`an pada wilayahwilayah yang tidak ilmiah. Persoalan subyektif dan obyektif, metode dan pendekatan, hubungan teks dan konteks, pembicara dan yang diajak bicara adalah tema-tema penting dalam studi terhadap teks apalagi teks yang dinilai suci dan berasal bukan dari karangan manusia tetapi dari Tuhan. Untuk itu studi al-Qur`an sudah saatnya diarahkan pada studi ilmiah dengan mengkaji tema-tema filosofis di atas dengan tepat. Pada masa kontemporer ini perkembangan ilmu linguistik, sastra, semiotik dan tafsir atau hermeneutika mencapai tingkat yang mengagumkan. Bahkan filsafat kontemporer juga memfokuskan diri pada bahasa, sehingga ada adegium bahwa inti segala persoalan kontemporer adalah bahasa. Dengan capaian-

${ }^{12}$ M. Quraish Syihab, Membumikan al-Qur'an, Fungsi dan Peran Wahyu dalam Kehidupan Masyarakat, (Bandung: Mizan,1999), h. 79. 
capaian keilmuan ini diskursus studi al-Qur`an dimungkinkan untuk mencerahkan landasan filosofis dan metodologinya.

\section{Awal Kajian Ilmiah atas Bahasa di Barat (Strukturalisme)}

Membicarakan tafsir dan hermeneutik tidak bisa melewatkan studi tentang bahasa karena obyek tafsir adalah teks. Untuk itu diperlukan pengertian mendalam mengenai apa itu bahasa yang menjadi pondasi dari suatu teks dan bagaimana mengkajinya secara ilmiah.

Dunia Barat mengakui bahwa kajian ilmiah mengenai bahasa baru dimulai sejak awal bad ke-20. Peletak dasar apa yang kemudian disebut ilmu bahasa atau linguistik modern adalah Ferdinann de Saussure (1857-1913). Dia adalah orang Swiss yang untuk beberapa waktu mengajar di Paris dan akhirnya menjadi profesor di Jenewa di mana ia mendirikan apa yang disebut "Mazhab Jenewa". Buku yang mengakibatkan namanya menjadi tersohor di bidang linguistik diterbitkan secara anumerta oleh dua orang muridnya dan diberi judul Cours de Linguistique Generale $(1916)^{13}$. Ada tiga pembedaan yang dilakukan Saussure sehingga bahasa dapat di kaji secara obyektif dan ilmiah.

1. Signifiant dan Signifie (tanda dan yang ditandai)

Menurut Saussure tanda bahasa bukanlah daftar kata-kata semata. Tanda Bahasa menyatukan konsep dan citra akustis, bukan benda dan nama" ${ }^{14}$ Kata "pohon" tidak menunjuk kepada pohon yang hidup di situ, tetapi menunjuk pada konsep tentang pohon. Suatu tanda bahasa bermakna bukan karena referensinya kepada benda dalam realitas. Yang ditandakan dalam tanda bahasa buka benda, tetapi konsep tentang benda. Konsep itu tidak lepas dari tanda bahasa, tetapi termasuk tanda bahasa itu sendiri. Makna tidak dapat dilepaskan dari kata. Untuk itu tanda bahasa (seperti misalnya suatu kata) yang dipelajari oleh Linguistik terdiri atas dua unsur, yaitu: le signifiant dan le signifie; the signifier and the signified, penanda dan yang ditandakan. Signifiant adalah bunyi yang bermakna atau

\footnotetext{
${ }^{13}$ Harimurti Kridalaksana, Mongin Ferdinand De Saussure (1857-1913) Bapak Linguistik dan Pelopor Strukturalisme, dalam; Ferdinand de Saussure, Pengantar Linguistik Umum, Penerjemah: Rahayu S. Hidayat: (Yogyakarta: Gadjah Mada University Press, 1988), h. 2.

${ }^{14}$ Saussure, Pengantar..., h. 12.
} 
coretan yang bermakna. Apa yang dikatakan atau didengar atau apa yang dibaca dan apa yang ditulis. Sedangkan signifie adalah gambaran mental, pikiran atau konsep. Kedua unsur itu tidak bisa dilepaskan.

Pembedaan tersebut mempunyai konsekuensi besar terhadap linguistik sehingga memiliki objek tersendiri. Karena kata menyatu dengan maknanya, maka untuk mengetahui makna bahasa tidak perlu lagi merujuk kepada unsur-unsur luar atau ekstra-lingual (luar bahasawi). Selain itu dalam Linguistik tidak perlu memandang subjek yang bicara. Dengan demikian ilmu bahasa menjadi otonom sehingga fenomena bahasa dapat dianalisa dan dijelaskan tanpa mendasarkan diri kepada apapun di luar bahasa. ${ }^{15}$

2. Langage, Parole dan Langue

Langage adalah fenomena bahasa secara umum yang didalamnya ada unsur sistem (langue) dan unsur individu (parole). Dalam fenomena bahasa itu harus dibedakan antara parole dan langue. Parole adalah keseluruhan apa yang diujarkan orang, manivestasi individu dari bahasa. Jadi parole bukan fakta sosial karena seluruhnya merupakan hasilindividuyanghadir. ${ }^{16}$ Sedangkan langue adalah bahasa sejauh merupakan milik bersama dari suatu golongan bahasa tertentu. Langue adalah keseluruhan kebiasaan yang diperoleh secara pasif yang diajarkan oleh masyarakat bahasa, yang memungkinkan penutur saling memahami dan menghasilkan unsur-unsur yang dipahami penutur dalam masyarakat. Dengan kata lain langue adalah sistem. Linguistik menurut Saussure tidak mempelajari parole, tetapi hanya mempelajari langue. ${ }^{17}$ Hal ini diumpamakan dengan permainan catur. Untuk mengerti dan bisa bermain catur orang tidak perlu tahu bahwa permainan tersebut berasal dari Parsi. Orang juga tidak perlu memperhatikan bahanbahan pembuat buah catur, apakah buah catur itu dibuat dari kayu, emas, atau gading. Permainan catur adalah sistem relasi-relasi di mana setiap buah catur mempunyai fungsinya dan sistem tersebut dikonstitusikan oleh aturan-aturannya. Jadi agar orang bisa main

${ }^{15} \mathrm{~K}$. Bertens, Filsafat Barat Kontemporer Jilid II Perancis, (Jakarta: PT. Gramedia, Pustaka Utama, 2001), h. 181.

${ }^{16}$ Saussure, Pengantar..., h. 6.

${ }^{17} \mathrm{Ibid}$, h. 6-7. 
catur, cukup tahu aturan-aturannya tersebut.

Demikian juga bahasa, tidak penting untuk mengetahui bahan dari mana bahasa itu berasal, artinya siapa yang berbicara dan apakah suaranya bagus atau tidak, siapa yang menulis, memakai tinta cair atau tinta kering. Yang penting dalam bahasa adalah aturan-aturan yang mengkonstitusikannya. Yang penting untuk dipelajari adalah susunan unsur-unsur-nya dalam hubungan satu sama lain. Bahasa adalah keseluruhan sistematis yang terdiri dari unsur-unsur yang masing-masing mempunyai fungsinya sendiri.

Setiap tanda bahasa mewujudkan suatu nilai yang tercantum dalam sistem bahasa bersangkutan menurut perbedaannya dengan tanda-tanda lain yang mewujudkan nilai-nilai lain. Dengan demikian hubungan antara signifiant dan signifie harus bersifat arbitrer,dalam artian setiap tanda bahasa mendapat nilainya hanya karena tercantum dalam sistem bahasa dan bukan karena salah ciri natural. ${ }^{18}$

\section{Sinkronik dan Diakronik}

Istilah sinkroni dan diakroni berasal dari kata Yunani khronos (waktu) dan awalan syn berarti bersama dan dia berarti melalui. Jadi sinkroni berarti bertepatan menurut waktu dan diakroni berarti menelusuri waktu. Dengan kata lain sinkroni adalah peninjauan yang ahistoris, mengabaikan perspektif historis dan diakroni adalah suatu peninjauan histories. ${ }^{19}$

Bahasa dapat dipelajari dari sudut pandang historis (diakronik) dengan meneliti dari perspektif sistem yang berfungsi pada saat tertentu, mengenai perkembangan suatu bahasa dari waktu ke waktu. Namun Saussure tidak setuju pandangan tersebut, karena bahasa adalah suatu sistem sebagaimana dijelaskan dalam pembedaan langue dan parole. Maka linguistik hanya mempelajari sistem bahasa sebagaimana dipakai sekarang ini, dengan tidak mempedulikan perkembangan dan perubahan yang telah menghasilkan sistem tersebut.

Saussure tidak menolak sepenuhnya penelitian diakroni, namun penyelidikan sinkronis harus mendahului penyelidikan

\footnotetext{
${ }^{18}$ K. Bertens, Filsafat..., h. 182-183.

${ }^{19} \mathrm{Ibid}, \mathrm{h} .184$.
} 
diakronis. Linguistik komparatif-historis harus membandingkan bahasa-bahasa sebagai sistem-sistem, karena itu lebih dahulu sistem harus dilukiskan tersendiri. ${ }^{20}$

\section{Subyektifitas dan Obyektifitas dalam Studi Teks Post Strukturalis}

Berkat jasa Saussure linguistik memperoleh kedudukan istimewa dalam ilmu pengetahuan manusia (humaniora). Bahasa dapat dipelajari secara obyektif karena bahasa dianggap suatu sistem yang otonom yang hanya memperhatikan relasi-relasi unsur di dalamnya, terlepas dari unsur luar yaitu siapa yang menggunakannya dan segala proses evolusi atau sejarah. Dengan demikian linguistik mendapat objek yang jelas dan metode yang sesuai dengan objeknya.

Namun dengan hanya menyelidiki langue yang berarti ilmu bahasa hanya menyelididki sistem bahasa atau struktur internalnya, dan sama sekali mengabaikan unsur luar seperti parole atau subyek yang menggunakan bahasa (yang berbicara) dan sejarah, maka pemikir setelah Saussure mulai merasa ragu. Benarkah bahasa sepenuhnya ditentukan oleh struktur dan subyek sama sekali tidak memiliki wewenang dalam bahasa?, padahal manusia merupakan agen atau pelaku sejarah. Manusia memang menjadi obyek sejarah tetapi juga tidak bisa dinafikan eksistensinya sebagai subyek sejarah. Menjawab semua keraguan tersebut, di lingkungan akademisi Perancis tahun 1960-an telah lahir beberapa ahli. Mereka tidak menolak struktur, namun manusia juga tidak bisa dipinggirkan, Kalau Saussure digolongkan sebagai pemikir strukturalis, maka pemikir sesudahnya yang mengkritisinya dikenal dengan pos struktural. Di antara mereka yang akan dikaji dalam makalah ini adalah Paul Ricoeur.

Para strukturalis, kata Ricoeur, berhak mempelajari bahasa sebagai langue, tetapi mereka melampaui batas kalau mereka menyamakan bahasa dengan langue. Di samping bahasa sebagai langue, ada lagi bahasa sebagai parole, yaitu subyek yang berbicara. Dengan berbicara subyek melebihi bahasa sebagai sistem tertutup,karena ia mampu mengatakan sesuatu yang sungguh-

${ }^{20}$ Saussure, Pengantar..., h. 10-11. 
sungguh baru. ${ }^{21}$ Kesatuan langue dan parole inilah awal pijak dari pemikiran Ricoeur.

Pandangan Ricoeur didasarkan pada fenomena bahasa sebagai wacana, yaitu bahasa yang digunakan. Strukturalis, menurut Ricoeur telah mengabaikan takdir bahasa sebagai wacana. Beberapa unsur wacana tidak mendapat tempat, seperti tiadanya tempat bagi temporalitas. Wacana selalu diungkapkan pada waktu tertentu dan konteks tertentu. Wacana selalu mengacu pada wahana atau dunia tertentu untuk digambarkan atau direpresentasikan untuk mengatakan sesuatu tentang sesuatu. Wacana selalu mempunyai subyek yang mengatakan dan interlocutor kepada siapa pesan itu disampaikan. Tiadanya aspek ini berarti analisis struktural mengabaikan proses komunikasi di dalam bahasa. ${ }^{22}$

Dengan pandangannya tentang bahasa sebagai wacana, maka Ricoeur telah membawa linguistik sebagai fondasi kajian teks atau hermeneutika. Analisis struktural tidak ditolak oleh Ricoeur karena bisa menjadi sarana logis untuk menjelaskan hubungan-hubungan, kombinasi dan kontradiksi-kontradiksi yang ada dalam teks untuk di atasi atau dipecahkan sehingga menolong bagi pemahaman teks. Dengan demikian bagaimana posisi dan peran obyek dan subyek dalam bahasa dan bagaimana relasi antar keduanya dalam proses penafsiran.

Menurut Ricoeur, tanda hanya mengacu kepada tanda lain dalam satu sistem. Namun dalam kalimat, bahasa diarahkan pada hal di balik dirinya sendiri, dimana makna bersifat imanen terhadap wacana dan tentunya bersifat obyektif dalam makna ideal, namun referensi justru mengekspresikan adanya pergerakan di mana bahasa mentransendensikan dirinya sendiri. Dengan kata lain, makna menghubungkan antara identifikasi fungsi dan fungsi predikat dalam kalimat, dan referensi menghubungkan bahasa dengan dunia. ${ }^{23}$ Secara ringkas, teks memiliki struktur imanen yang bisa dijelaskan dengan pendekatan struktural, tetapi teks sekaligus

\footnotetext{
${ }^{21}$ K. Bertens, Filsafat..., h. 229-220.

${ }^{22}$ Haryatmoko, Hermeneutika Paul Ricoeur, Transparansi Sebagai Proses, No 0506: Tahun ke-49, Mei-Juni 2000, h. 30.

${ }^{23}$ Paul Recoeur, Filsafat Wacana, Penerjemah: Musnur Heri, (Yogyakarta: IRCiCHOD, 2003), h. 41.
} 
mempunyai acuan luar (referensi) yang melampaui linguistik dan filsafat bahasa. Acuan luar itu yang disebut wahana atau dunia teks, realitas yang digelar oleh teks, suatu totalitas makna atau cakrawala global. ${ }^{24}$

Recoeur membedakan antar bahasa lisan dan tulis dan menetapkan bahasa tulis sebagai obyek hermeneutika. Dengan ditulis, maka bahasa bisa menunjuk pada dunia di luar dirinya dan ditujukan pada alamat yang tidak tertentu. Dengan pandangan ini, Josef Blecher mensimpulkan adanya beberapa teori teks menurut pemikiran Ricoeur; 1) Penulisan akan menetapkan makna (fixation of meaning), 2) Dengan penulisan, maka maksud dari pengarang akan beripisah dengan makna teks. Teks akan mengembara dengan dunia sendiri terlepas dari cakrawala penulis, 3) Dengan penulisan, teks akan melampau referensi awal saat disampaikan. ${ }^{25}$

Dengan demikian dapat disimpulkan bahwa di dalam teks ada makna objektifyang dapat ditangkap dengan analisis struktural, dengan hanya mengetahui sistem yang mengatur relasi-relasi antar unsur di dalam teks itu sendiri. Namun bahasa dalam kodratnya adalah untuk mengatakan atau mengungkapkan sesuatu, maka selain struktur internal, bahasa juga memiliki referensi atau acuan luar atau dunia teks. Inilah makna subyektif dari teks.

Acuan luar atau dunia teks itu baru akan bermakna apabila menjadi milik pembaca atau penafsir, apropiasi atau pemahaman diri. Pemahaman diri inilah menandai pertemuan antara dunia yang disarankan oleh teks dan dunia konkret pembaca. Pembauran ini terjadi karena penafsir tidak mungkin mengambil alih dunia teks secara keseluruhan dan meninggalkan dunianya sendiri yang aktual yang dihayatinya sekarang. ${ }^{26}$ Sampai disinilah bahaya subyektifitas muncul. Namun Ricoeur telah memiliki jurus penyelesaiannya, dalam proses pemahaman diri tersebut sangat diperlukan pengambilan jarak terhadap diri sendiri sehingga tidak terjadi distorsi makna dan dapat merelativisasi kesewenangwenangan dalam penafsiran.

\footnotetext{
${ }^{24}$ Haryatmoko, Hermeneutika..., h. 30.

${ }^{25}$ Josef Bleicher, Contemporary Hermeneutics, Hermeneutics as Method, Philosphy and Critique, (London and New York: Routledge, 1993) h. 230.

${ }^{26}$ Haryatmoko, Hermeneutika..., h. 31.
} 
Untuk melakukan pengambilan jarak, Ricoeur menawarkan jalan berbentuk kritik ideologi dan dekonstruksi. Kritik ideologi untuk menjadikan kritik dan serangan dari luar yang mungkin destruktif dan dapat melemahkan eksistensi teks (agama) dapat diterima sebagai otokritik untuk pemurnian diri. Dekonstruksi mengajak pembaca untuk membongkar ilusi-ilusi, motivasi-motivasi baik sadar maupun di bawah sadar, serta kepentingan-kepentingan diri atau kelompok di depan teks. ${ }^{27}$

\section{E. Bahasa dan Studi al-Qur`an Muhammad Syahrur}

Syahrur adalah Profesor di jurusan Teknik Sipil Universitas Damaskus dengan latar belakang ilmu Mekanika Tanah dan Teknik Pondasi. Namun ia menunjukkan komitmen dan konsistensinya ketika tertarik dan menekuni studi al-Qur`an. Ia mengkritik kelemahan yang dilakukan mufassir sebelumnya adalah tidak memiliki pegangan metode ilmiah obyektif. Untuk mengawali karirnya di bidang studi al-Qur` an ia berguru kepada ahli linguistik Dalam pengantarnya Syahrur menuturkan bahwa pada tahun 1980 ia bertemu dengan dosen linguistik Ja` far Dak al-Bab dalam sebuah organisasi etnis di Uni Soviet. Pertemuan tersebut menyadarkan Syahrur bahwa sebenarnya ia tertarik pada studi linguistik, filsafat, dan studi al-Qur`an. Ja'far menunjukkan disertasi doktoralnya yang diseminarkan di Universitas Moskow tahun 1973 dengan tema pembahasan teori linguitik Abdul Qahir al-Jurjani dan posisinya dalam konstalasi linguistik umum. Dari dosen linguistik itulah Syahrur mengakui telah mengenal para linguis di lingkungan pemikir Arab seperti al-Farra, Abu Ali al-Farisi dan muridnya Ibnu Jinni serta Abdul Qahir al-Jurjani. ${ }^{28}$

Untuk mengetahui pokok pikiran yang diadop oleh Syahrur dari linguis Arab, Ja`far Dak al-Bab telah memberikan pengantar dalam penerbitan karya perdana Syahrur al-Kitab wa al-Qur`an. Ja`far menggabungkan teori Ibnu Jinni dan al-Jurjani, namun tetap bersumber dari satu aliran yaitu linguistik Abu Ali al-Farisi. Pamikiran utama dari teori tersebut adalah:

\footnotetext{
${ }^{27}$ Ibid., h. 31-32.

${ }^{28}$ Muhammad Syahrur, al-Kitāb..., h. 47.
} 
1. Penggabungan antara studi diakronik al-Jurjani dan sinkronik Ibnu Jinni.

2. Teori Ibn Jinni yang menyatakan bahwa bahasa tidak terbentuk seketika dan teori al-Jurjani tentang hubungan antara bahasa dan pertumbuhan pemikiran merupakan hal yang saling terkait. Dengan demikian, bahasa dengan segala aturannya tumbuh dan berkembang seiring dengan pertumbuhan pemikiran manusia.

Adapun ciri linguistik Abu Ali al-Farisi dapat disimpulkan bahwa : a) bahasa pada dasarnya adalah sebuah sistem, b) bahasa merupakan fenomena sosial dan strukturnya terkait dengan fungsi transmisi yang melekat pada bahasa tersebut. c) adanya kesesuaian antara bahasa dan pemikiran. ${ }^{29}$

Pandangan-pandangan di atas menunjukkan telah terjadi modernisasi dalam pemikiran linguistik di Arab yang keluar dari pemikiran ortodoks yang menyatakan bahwa bahasa Arab adalah bahasa khusus karena ia adalah bahasa suci, bahasa yang digunakan Tuhan untuk menyampaikan wahyunya, sehingga bahasa tidak terkait dengan pemikiran dan struktur sosial masyarakatnya. Meskipun nampak aliran-aliran di atas sangat terkait dengan strukturalisme namun ia telah menunjukkan sikap kritisnya sehingga unsur-unsur historis diterima dalam linguistik tanpa menafikan adanya struktur.

Modernisasi dalam linguistik tersebut membuka peluang bagi Syahrur untuk merumuskan prinsip-prinsip dalam studi al-Qur`an:

a. Memaksimalkan seluruh potensi karakter linguistik Arab dengan bersandar pada tiga pondasi, yaitu metode linguistik Abu Ali al-Farisi, perspektif linguistik ibnu Jinni dan Abdul Qahir al-Jurjāni dan syair Arab Jahiliyah.

b. Bersandar pada produk akhir ilmu linguistik modern yang menyatakan bahwa bahasa manapun tidak memiliki karakter sinonim. Sebuah kata dalam koridor historisnya, mengalami dua alternatif proses yaitu akan mengalami kehancuran atau membawa makna baru selain makna asalnya.

${ }^{29}$ Ibid., h. 21-22. 
c. Jika Islam bersifat relevan pada setiap ruang dan waktu, maka harus dipahami bahwa al-Kitab juga diturunkan kepada kita yang hidup pada abad dua puluh ini, seolah-olah Nabi Muhammad baru saja wafat dan telah menyampaikan sendiri kepada kita. Kitab-kitab tafsir dan fiqh yang dihasilkan generasi terdahulu harus dipandang sebagai intekasi mereka dengan al-Kitab dalam sejarah mereka.

d. Allah tidak perlu memberi petunjuk - berupa al-Kitab untuk diri-Nya sendiri. Maka Dia menurunkannya sebagai petunjuk bagi manusia. Oleh karena itu seluruh kandungan al-Kitab pasti dapat dipahami sesuai dengan kemampuan akal. Al-Kitab diturunkan dalam sebentuk media yang sesuai dengan kapasitas pemahaman manusia. Media tersebut berupa linguistik Arab Murni (al-Lisān al-Arabi al-Mubīn). Tidak ada kontradiksi antara bahasa dan pemikiran, maka tidak ada ayat yang tidak bisa dipahami dan pemahaman terhadap al-Kitab selalu bersifat relatif, historis, dan temporal.

e. Tidak ada pertentangan antara akal dan wahyu, dan tidak ada pertentangan antara wahyu dan realitas yang berupa kebenaran informasi dan rasionalitas penetapan hukum.

f. Lebih menghormati akal pembaca daripada gejolak emosinya. ${ }^{30}$

Konsekuensi logis pertama dari prinsip di atas adalah perombakan cara pandang terhadap al-Qur'an sebagai obyek studi ilmiah. Dalam filsafat ilmu merupakan suatu yang wajib untuk membicarakan hakekat obyek sebelum membahas metode yang sesuai. Kalau bahasa dinilai sebagai sebuah sistem yang terkait dengan pemikiran dan realitas sosial yang memiliki dimensi ruang dan waktu (hostoris), bagaimana dengan al-Qur`an yang dianggap kalam Tuhan yang suci bebas ruang dan waktu namun memiliki wujud yaitu teks kebahasaan.

Menjawab problematika di atas Syahrur menawarkan dua alternatif jawaban, 1. al-Kitab dan isinya adalah karya Muhammad, 2. al-Kitab dan isinya diwahyukan oleh Tuhan berupa teks (al-nash) beserta kandungannya (al-muhtawa). Syahrur mengarah pada

${ }^{30}$ Muhammad Syahrur, al-Kitāb..., h. 44-45. 
pilihan kedua bahwa al-Qur`an adalah dari Tuhan, namun untuk menerima pilihan kedua, syahrur mewajibkan suatu konsekuensi sebagai berikut:

1. Karena Allah bersifat absolut, memiliki kesempurnaan pengetahuan, dan tidak memiliki sifat relatif, maka kitabkitab-Nyapun -pada sisi kandungannya (al-muhtawā)mengandung unsur-unsur yang absolut.

2. Karena Allah tidak perlu mencurahkan ilmu dan petunjuk bagi diri-Nya sendiri, maka kitab ini-yang merupakan kitab penutup -diturunkan sebagai petunjuk bagai manusia. Dengan demikian pada sisi pemahamannya (al-fahm alInsāni) ia harus memuat unsur-unsur yang relatif.

3. Karena kesempurnaan cara berpikir manusia dicapai melalui bahasa, maka ada dua konsekuensi, yaitu: pertama, kitab ini dimanifestasikan dalam bahasa manusia. Kedua, kitab ini harus memiliki karakter khusus, yaitu muatannya bersifatabsolutdan pemahamannya bersifatrelatif.Karakter tersebut terlihat meniscayakan adanya dimensi sakralitas pada teks ayat-ayat al-Kitab yang tidak mungkin berubah. Pada saat yang sama memiliki dinamika pemahaman (harakah at-ta`wil) yang sesuai dengan perjalanan sang waktu. ${ }^{31}$

\section{F. Sintesa Antara Recoeur dan Syahrur}

Al-kitab -Syahrur membedakannya dengan al-Qur`andalam pemikiran Syahrur bukan teks budaya dalam pengertian yang dihasilkan oleh manusia, tetapi wujud teks al-Kitab adalah teks berbahasa Arab, dimana bahasa Arab adalah hasil budaya masyarakat Arab yang tidak bisa dilepaskan dengan struktur nalar dan sosial masyarakat Arab. Untuk itu Syahrur berkesimpulan bahwa dari sisi kandungannya (al-muhtawā) mengandung unsur ilahiah yang absolut, Namun pada sisi pemahaman terhadap al-Kitab bersifat insani yang relatif. Manusia tentu tidak bisa menangkap keseluruhan wahyu yang absolut, untuk menangkapnya Tuhan telah menurunkan wahyu dengan medium yang memungkinkan manusia bisa memahaminya yaitu bahasa. Dengan demikian,

${ }^{31}$ Muhammad Syahrur, al-Kitāb..., h. 36. 
relatifitas yang dimaksud Syahrur adalah relatifitas dalam kerangka hubungan antara pembaca dengan teks al-Qur`an yang berbahasa Arab.

Hubungan pembaca dengan teks al-Qur`an yang berbahasa Arab (insāni) meniscayakan ilmu bahasa sebagai sebuah metode penafsiran untuk menangkap makna al-Qur`an. Syahrur menetapkan pemikiran linguistik kontemporer sebagai rujukan, hal ini sebagai bentuk konsistensi Syahrur terhadap pernyataannya tentang temporarilitas pemahaman. Sebagai manusia yang hidup di zaman kontemporer, maka harus memaksimalkan seluruh pemikiran kontemporer. Namun Syahrur juga tidak asal comot dan pilih teori, terbukti Syahrur berinteraksi dengan baik dengan linguis Arab kontemporer.

Berbeda dengan semua teks hasil budaya yang ada yang ditulis sebagai ungkapan kegelisahannya pada masa itu atau sebagai respon terhadap situasi zaman tertentu dimana ia menetap dan berkarya, al-Kitab sebagai wahyu memang ditujukan kepada semua manusia di segala tempat dan segala zaman. Untuk itu menurut Syahrur pemahaman kita terhadap teks al-Kitab tidak bisa dibatasi atau ditentukan oleh satu pemahaman dari periode masyarakat tertentu termasuk periode nabi Muhammad saw. Pemahaman yang dilakukan nabi dan sahabat dianggap Syahrur sebagai contoh pertama pemahaman terhadap al-Qur`an untuk mengahadapi masalah zamannya. Di sinilah muncul persoalan hermeneutik yaitu jarak antara teks yang diturunkan di sana pada zaman dahulu dengan kita yang di sini yang hidup dengan permasalah zaman ini,

Mengahadapi persoalan jarak tempat dan waktu, nampak titik-titik temu antara pemikiran Syahrur dan Recoeur. Menurut Recoeur teks adalah otonom, untuk memahami teks tidak perlu dikembalikan kepada penulis atau pembuat teks tersebut dan situasi awal saat pertama kali diungkapkan. Hal itu mungkin dilakukan, karena menurut Recoeur dengan ditulisnya wacana maka wacana terpatri kedalam tulisan yang tidak lagi berubah sehingga teks dapat menjangkau kita yang hidup pada zaman ini di sini. Untuk itu menurut Recoeur tugas hermeneutik adalah mencari di dalam teks itu sendiri dinamika yang di arah oleh strukturasi karya dan 
mencari di dalam teks kemampuan karya untuk memproyeksikan diri keluar dari dirinya dan melahirkan satu dunia yang merupakan halnya atau pesan dari teks itu.

Tanpa menyederhanakan hermeneutika yang telah dipikirkan oleh Syahrur, namun nampak usaha Syahrur yang cukup gemilang pada dua tugas hermeneutik sebagaimana diungkapkan Recoeur. Dalam studinya mengenai al-fiqh al-Islāmi pada tema-tema perempuan, ia menunjukkan analisis struktural yang luar biasa terhadap teks al-Qur`an. Syahrur dengan bekal linguistik kontemporer bisa menemukan struktur khas dari teks al-Qur`an dan tidak ada satu unsurpun yang sia-sia dan tidak ada fungsinya sebagaimana dikemukakan oleh kalangan nühah klasik. Setelah analisis struktural, untuk menemukan makna totalitas yang diarah oleh teks, Syahrur juga menggunakan filsafat dan ilmu pengetahuan kontemporer. Sebagaimana Recoeur, Syahrur menggunakan kekayaan ilmu kotemporer seperti filsafat, sosiologi, antropologi dan politik tidak seperti kalangan apologetik yang menempatkannya sebagai hamba teks, namun ilmu-ilmu tersebut ditempatkan dalam dialektika kritis dengan makna teks untuk menuju pemahaman yang lebih baik. Dengan dialektika kritis dengan khazanah ilmu kontemporer akan dicapai pemahaman yang lebih baik, tidak sekedar dalih bahwa teks tidak bertentangan dengan rasio atau ilmu pengetahuan. Tetapi teks memberi cara pandang dan dasar-dasar bagi pencerahan ilmu-ilmu kontemporer.

\section{G. Penutup}

Menemukan makna yang asli yang dimaksud oleh pengarang sebagaimana dikehendakai oleh ahli tafsir zaman pertengahan sangat mustahil untuk dilakukan, karena manusia tidak bisa melepaskan lingkup historisnya kini, keluar dari zaman di mana penafsir hidup sekarang, kemudian memasuki alam pikiran sejarah masa lalu di mana suatu teks dihasilkan. Recoeur memberikan satu jalan keluar, karena meskipun manusia tidak dapat hadir seutuhnya ke masa lalu, namun berkat ditulisnya suatu teks ke dalam tulisan, maka teks sebenarnya dapat hadir ke zaman di mana kita berada sekarang ini. Dengan ditulis, teks menjadi otonom terlepas dari maksud pengarang dan alamat awal di mana teks itu dilahirkan. 
Penafsir tidak perlu terjebak dalam subyektifitas, karena teks memiliki makna obyektif dalam struktur internalnya. Namun makna dari struktur internal tersebut tidaklah sepenuhnya membunuh subyek, karena teks selalu akan menunjuk atau mengacu pada suatu dunia tertentu, maka penafsiran selain menemukan makna obyektif teks, juga menemukan cakrawala dunia yang di arah oleh teks. Sehingga penafsir meleburkan diri dalam dunia teks.

Pandangan Recoeur di atas menjadi sumbangan yang berarti dalam studi al-Qur`an kontemporer yang berobsesi kembali kepada pandangan hidup al-Qur`an tetapi tidak terjebak dalam kejumudan dan kungkungan masa lalu. Sebagaimana pemikiran Syahrur, kembali kepada al-Qur`an tidak berarti kembali kemasa lalu, kembali kepada penafsiran yang ditangkap oleh Nabi dan para sahabat. Menafsirkan al-Qur` an adalah menggali pandangan hidup al-Qur`an atau makna dari totalitas struktur al-Qur`an. Makna alQur`an juga memberikan acuan kepada dunia kontemporer saat ini.

Di antara pemikiran Syahrur yang perlu dikritisi adalah masalah hubungan al-Qur`an dengan sunnah Nabi. Makna yang ditangkap oleh Nabi dan masyarakatnya saat itu memang bukanlah makna yang sakral dan baku sesuai makna yang dikehendaki oleh Tuhan. Secara hermeneutis makna zaman itu adalah makna aktual yang mengacu dan sesuai dengan zaman itu. Namun menganggap makna zaman Nabi itu sama sekali tidak dibutuhkan dalam penafsiran kontemporer agar umat saat ini tidak terkurung oleh masa lalu juga meragukan, karena bagaimanapun kita tidak dapat melepaskan al-Qur`an dari dunia Arab saat Nabi, sebagai dunia di mana bahasa Arab digunakan Tuhan untuk media penyampaian wahyu-Nya. Dalam hermeneutika kontemporer, sejarah masa Nabi dapat dinilai sebagai jembatan untuk memahami teks, namun jembatan itu tidak dapat dimutlakkan sehingga penafsir dapat sampai pada cakrawala teks yang mengacu pada dunia masa kini. 


\section{Daftar Pustaka}

af-Farmawi, 'Abd Al-Hayy, Metode Tafsir Mawadhu'iy Suatu Pengantar, Penerjemah: Suryan A. Jamrah, Jakarta: Rajawali Pers, 1996.

Amstrong, Keren, Berperang Demi Tuhan, Fundamentalisme dalam Islam,Kristen dan Yahudi, Bandung: Mizan dan Serambi, 2000.

an-Najdi, 'Abd al-Rahmān bin Muhammad bin Qāsim al-'Așim, Majmü' Fatāwā Syaikh al-Islām Ahmad bin Taimiyah, juz ke-13, ttp : tpn, 1398 H.

az-Zarkasi, Badr al-Dīn Muhammad bin 'Abd Allāh, al-Burhān fi 'Ulūm al-Qur'ān, juz ke-2, Beirut: Dār al-Fikr, 1998.

Bleicher, Josef, Contemporary Hermeneutics, Hermeneutics as Method, Philosphy and Critique, London and New York: Routledge, 1993.

Bertens, K., Filsafat Barat Kontemporer Jilid II Perancis, Jakarta: PT. Gramedia, Pustaka Utama, 2001.

Haryatmoko, Hermeneutika Paul Ricoeur, Transparansi Sebagai Proses, No 05-06: Tahun ke-49, Mei-Juni 2000.

Syihab, M. Quraish, Membumikan al-Qur'an, Fungsi dan Peran Wahyu dalam Kehidupan Masyarakat, Bandung: Mizan,1999.

Manna al-Qațtān, mabāhì fì 'Ulūm al-Qur'ān, Riyāḍ: Mansyurāt al-'Așr al-Ḥadiss, 1973.

Syahrur, Muhammad, al-Kitāb wa al-Qur`ān, Qirā’ah Mu'as\}irah, Damaskus: al-Ahali, 1990.

Zaid, Nașr Hamid Abu, Mahfūm al-Naṣ, Dirāsah fī 'Ulūm al-Qur'ān, Kairo: al-Hai'ah al-Mișriyyah al-Ammah li al-Kitāb, tt.) , Tekstualitas al-Qur'an, Kritik terhadap Ulumul Qur'an, Terj: Khoiron Nahdliyyin, Yogykarta: LkiS, 2001. 